\title{
Characteristics of Financial Accounting Transformation to Management Accounting in Big Data Environment
}

\author{
Fanyu Meng \\ North China Electric Power University, Baoding 071000, China. \\ Corresponding author: mengfy_ncepu@163.com
}

Keywords: Big data environment; financial accounting; management accounting;

\begin{abstract}
China has fully entered the era of big data. Under the background of the development of this era, the financial accounting of enterprises is gradually changing towards the direction of management accounting. First of all, the characteristics of big data are analyzed in detail. Based on that, the implementation of specific strategies for financial accounting transformation to management accounting is further studied.
\end{abstract}

\section{Transformation characteristics}

Under the background of continuous progress and development of science and technology, China has entered the era of big data. More and more new technologies are widely applied to various industries. Especially for modern enterprises, in the daily operation and management of enterprises, we must enhance their comprehensive competitiveness to occupy a favorable position in the fierce market. Under the current big data environment, more and more business managers have gradually realized the importance of big data. In order to improve their comprehensive strength and occupy a favorable position in the market, enterprises need to achieve rapid upgrading of business management On this basis, enterprises need to build information data processing system, and apply the system to financial management scientifically so that it can provide a supplementary role for the transformation of enterprises. Finance is an essential part of the daily operation of an enterprise. Especially when collecting, analyzing, integrating and processing some financial data, it is necessary to combine effectively with the strategic development of an enterprise. In order to ensure the authenticity and effectiveness of financial data, it can provide accurate and effective financial information data as support for enterprise's daily operation management and decision.

\section{Characteristic analysis of big data}

Under the background of the rapid development of network information technology, China has entered the era of big data. More and more information technologies are widely applied to various industries. Under such circumstances, the competition between enterprises is becoming more and more intense. Only by improving their comprehensive competitiveness in the market can enterprises occupy a favorable position and maximize their economic benefits. At the same time, influenced by the background of big data, more and more business managers have gradually realized the importance of big data in the daily operation and management of enterprises. Big data can also be called "huge data", that is to say, the amount of information data that it can generate is very large. Even if we use some mainstream software tools to operate at the present stage, it is difficult to satisfy the personalized demand of big data [1]. In this case, the enterprise directly uses the big data processing technology to realize the collection and application of the financial information data. At the same time, it can effectively integrate with the development strategy of enterprises, and build a scientific and reasonable management mode. What's more, these data are applied to the management mode, and provide accurate and effective financial information data as support for a series of decisions of enterprises. 


\subsection{Large data volume of big data}

Through the analysis of the characteristics of big data, we can see that the characteristics of big data are quite numerous, so the advantageous characteristics of its application are also obvious. In general, big data refers to a large set of data that can reach 10TB, which can cover a number of aspects. But through the investigation and analysis of the actual situation, we can see that the majority of enterprises will centrally manage multiple large data directly on the integration of data information users. In this case, the amount of data can reach PB level. From this, we can see that the data volume of enterprise big data is very large, and the data resources covered by it are very rich [2].

\subsection{Huge data category of big data}

The data of big data has quite rich resources, and the category of data is very large, which means that the data sources in big data have diversification characteristics. The source, form, category and format of big data are rich and changeable. The data in big data can break the limitation and mononeness of traditional data acquisition. Big data is no longer confined to structured data only. Instead, it directly uses some unstructured data or semi structured data mode to perform specific operations, as shown in Figure 1 [3].

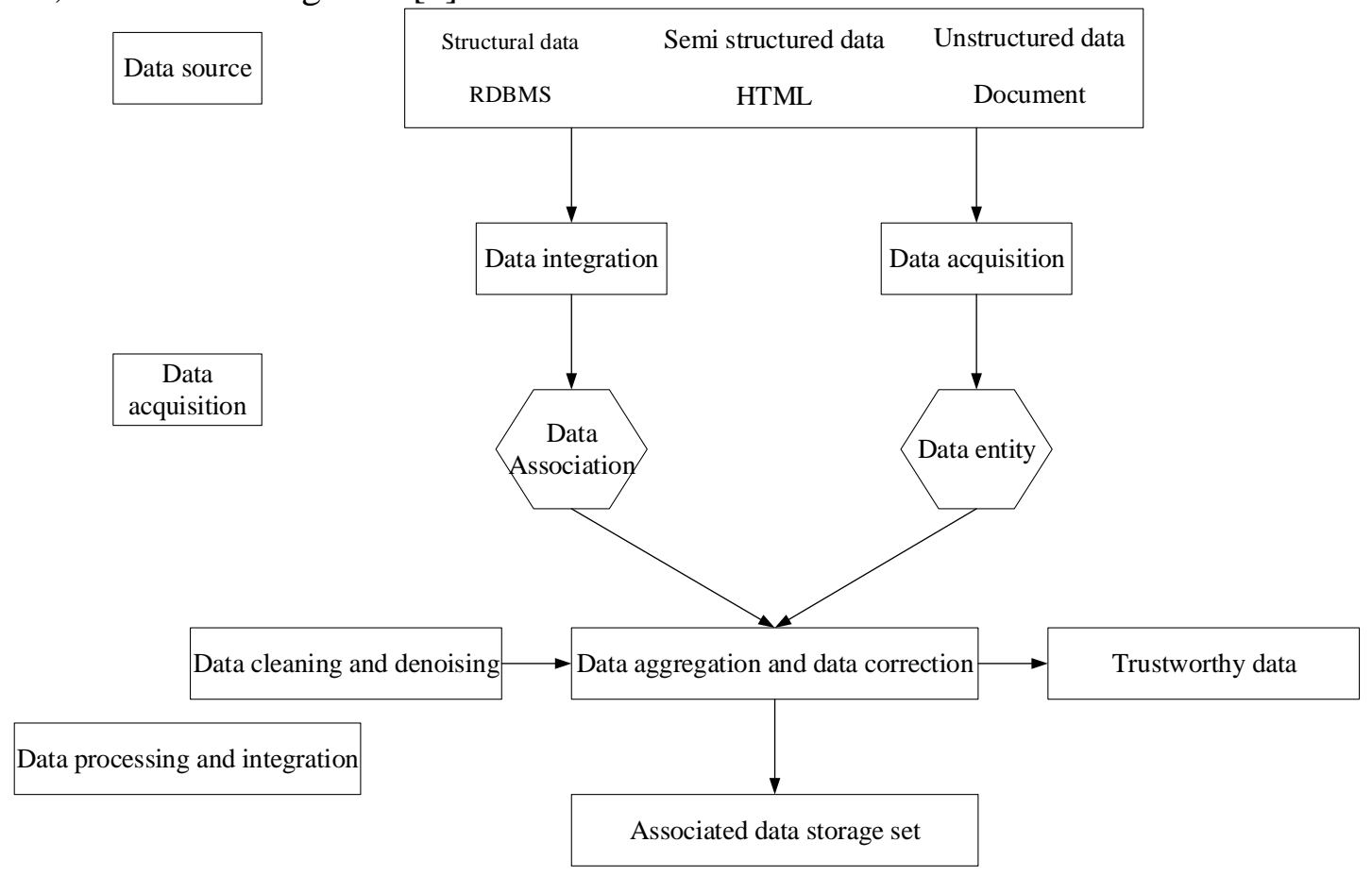

Figure 1 Big data characteristic schematic diagram

\section{An inevitable trend of the transition from financial accounting to management accounting under the background of big data}

Under the background of big data, more and more modern enterprises have gradually realized the importance of big data. In the process of financial management, financial accounting has gradually shifted to management accounting, and this transformation has become an inevitable trend. In the process of daily management, in most cases, the computer network technology will be used to collect, make statistics and deal with the related data directly. When dealing with a series of information generated in financial work, the application of Internet technology can not only speed up the processing of data information, but also effectively promote the quality and efficiency of financial data processing [4]. This means that when financial accounting performs its duties and obligations, it still needs the help of information technology. At the same time, on this basis, a systematic management mode can be constructed and applied in practice. The financial and accounting personnel can directly and effectively combine with the development of strategic thinking and systematic enterprise management thinking. This is not only conducive for the financial and accounting 
personnel to have a more in-depth understanding and recognition of enterprise value and ability, but also can provide effective help for the financial accounting transformation to management accounting.

Under the current big data environment, there is more and more information. This will lead to corresponding changes in the way or statistic method of financial accounting when it is concretely implemented. Especially when managing some kinds of financial data categories, because of the large number of various data, it is necessary to classify and manage [5]. According to the different types of management accounting, we put forward targeted management measures. And at the same time, it is necessary to combine with the actual situation and consider from the perspective of enterprise's strategic thinking, so as to ensure the improvement of quality and level of information data management.

\section{Analysis on the measures of financial accounting transformation to management accounting under big data background}

\subsection{To improve the comprehensive quality and the level of professional operation skills of the financial personnel}

Under the current big data environment, enterprises need to be aware of the important impact of big data on their future development if they expect to stand out in the market competition, improve their comprehensive competition and occupy a favorable position in the market. At the same time, because financial accounting is an essential part of modern enterprises in operation and management, enterprises must realize the integration of financial accounting and big data. Especially in the context of current big data environment, enterprise financial accounting can gradually transform into management accounting. In order to achieve this goal, financial personnel needs to have relatively high professional quality and professional skills. First of all, we should pay attention to the ideological education of financial personnel, and it is necessary to strengthen training in daily training process, so that financial personnel can realize the correct idea of financial management [6]. At the same time, enterprises can also make cultivation of the financial staff's thought according to the actual situation. As a result, financial management personnel can take enterprise's economic benefit thought as a prerequisite. In this way, it can make financial personnel fundamentally shifted focus gradually to solve the financial problems, and put forward rational solving measures for some non-financial problems.

\subsection{To strengthen the construction of enterprise financial information}

Under the background of big data environment, information technology is an essential technology, which can directly affect every link and process of enterprise's daily operation and management. Under the background of big data environment, enterprise financial accounting needs to be effectively combined with information technology in the direction of successful transition to management accounting. At the same time, it is effectively combined with the actual situation, to construct scientific and reasonable information management platform. Meanwhile, it is supposed to ensure that data information resources acquired in this platform has authenticity and validity, so as to provide an accurate basis for effective support to business decision. As shown in Figure 2, it is the basic content of the accounting. On this basis, it is effectively combined with these contents and it makes use of information technology to operate. In the meanwhile, it is necessary to increase the funds investment of information construction. In this way, it not only can fundamentally promote the quality and level of management information platform construction, but also can provide a good environment for fundamental financial accounting management of enterprises. In the process of financial information construction, we should pay attention to the introduction of some high-quality and highly skilled talents. These talents should not only have rich theoretical knowledge, but also need rich experience as the basis [7]. In addition, the information technology operation level and ability of these professionals also need to achieve certain standards and levels. Therefore, we can control the computer technology accurately and effectively, and achieve efficient management of enterprise's financial information. 


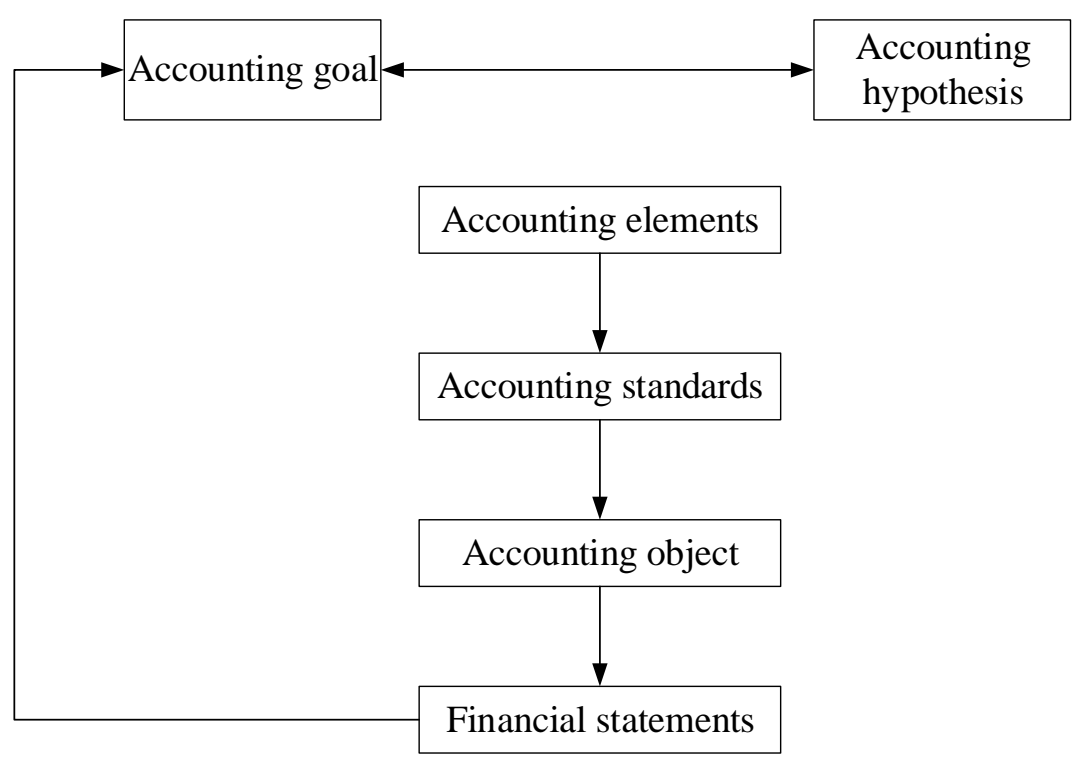

Figure 2 Schematic diagram of basic accounting content

\subsection{Financial accountants' aware of the foresight of financial accounting}

In the implementation process of enterprise financial accounting, it is mainly providing the budget analysis for a series of business activities of a company, and at the same time, the judgement of the business situation is given, giving accurate and effective financial advice. As shown in Table 1, the content is the category, meaning and content classification table of modern enterprises in the financial budget management. Only based on this can we predict and analyze the operation of enterprises in the present and future development. When enterprises are dealing with accounting information, they should have enough understanding and knowledge in particular for their foresight. The enterprise should take its strategic development as the foundation, and on this basis, combined with the actual situation, it requires to effectively formulate a scientific and reasonable management system. In this way, we can not only directly use accounting information to predict and analyze the operation rules of future accounting information, but also can apply these information to practice scientifically, and play a good role in maintaining assets of enterprises.

Table 1 Financial budget category, meaning, and corresponding content analysis

\begin{tabular}{|c|c|c|c|}
\hline Category & Meaning & Specific content & \\
\hline $\begin{array}{l}\text { Business budget } \\
\text { (operating } \\
\text { budget) }\end{array}$ & $\begin{array}{l}\text { A variety of budgets that } \\
\text { are directly related to the } \\
\text { daily business activities of } \\
\text { an enterprise }\end{array}$ & $\begin{array}{l}\text { Sales budget; production budget; } \\
\text { direct material budget; direct } \\
\text { artificial budget; manufacturing } \\
\text { cost budget; product cost budget; } \\
\text { sales and management cost } \\
\text { budget }\end{array}$ & \multirow{2}{*}{$\begin{array}{l}\text { Auxiliary } \\
\text { budget or } \\
\text { sub budget }\end{array}$} \\
\hline $\begin{array}{l}\text { Special decision } \\
\text { making budget }\end{array}$ & $\begin{array}{l}\text { An important decision } \\
\text { budget that does not occur } \\
\text { frequently in an enterprise }\end{array}$ & $\begin{array}{c}\text { Capital expenditure budget and } \\
\text { so on }\end{array}$ & \\
\hline Financial budget & $\begin{array}{l}\text { The budgets of the expected } \\
\text { cash balance, the financial } \\
\text { situation and the operating } \\
\text { results reflected by } \\
\text { enterprise in the planned } \\
\text { period. }\end{array}$ & $\begin{array}{l}\text { It occupies a pivotal position in } \\
\text { the overall budget, including: } \\
\text { cash budget, expected financial } \\
\text { statements (expected profit } \\
\text { statement and balance sheet) }\end{array}$ & $\begin{array}{l}\text { General } \\
\text { budget }\end{array}$ \\
\hline
\end{tabular}

\section{Conclusion}

In the background of the current big data environment, the transition from financial accounting to management accounting has gradually become an inevitable trend. At the present stage, enterprises 
realize the importance of big data. Especially in financial management, big data can play its role and value, providing accurate and effective decision-making basis for the daily operation and development of an enterprise. In order to promote the transformation speed effectively, enterprises need to integrate with the strategic thinking of enterprises, and lay a good foundation for the systematic development of accounting work.

\section{References}

[1] Warren Jr J D, Moffitt K C, Byrnes P. How Big Data will change accounting[J]. Accounting Horizons, 2015, 29(2): 397-407.

[2] Bhimani A, Willcocks L. Digitisation, 'Big Data'and the transformation of accounting information [J]. Accounting and Business Research, 2014, 44(4): 469-490.

[3] Waller M A, Fawcett S E. Data science, predictive analytics, and big data: a revolution that will transform supply chain design and management[J]. Journal of Business Logistics, 2013, 34(2): 77-84.

[4] Griffin P A, Wright A M. Commentaries on Big Data's importance for accounting and auditing[J]. Accounting Horizons, 2015, 29(2): 377-379.

[5] Wang G, Gunasekaran A, Ngai E W T, et al. Big data analytics in logistics and supply chain management: Certain investigations for research and applications[J]. International Journal of Production Economics, 2016, 176: 98-110.

[6] Schoenherr T, Speier - Pero C. Data science, predictive analytics, and big data in supply chain management: Current state and future potential[J]. Journal of Business Logistics, 2015, 36(1): 120-132.

[7] Wieder B, Chapman P, Thirathon U. Management Accounting in the Big Data Era-Opportunities or Threats?[C]//International Conference on Enterprise Systems, Accounting and Logistics. 2017. 